\title{
TRAINING OF BIL HIKMAH QURAN READING METHOD FOR ISLAMIC PRIMARY TEACHERS
}

\author{
Udin Supriadi,* Saepul Anwar and Usup Romli \\ Universitas Pendidikan Indonesia (UPI), Indonesia \\ *E-mail: udinsupriadi@upi.edu
}

\begin{abstract}
Every Muslim is encouraged to be able to read Quran. Therefore, it become the main purpose on the conduction of Islamic education, starting from primary level. Realistically, only 30\% students were able to meet the objective. One of the factors is due to the inappropriate learning method being used. In this case, Bilhikmah is introduced as a method to learn Quran shortly which has been effectively proved. The training aimed to provide the Islamic primary teachers with adequate knowledge of Bilhikmah method. The considered target in this study is $75 \%$ from 40 teachers would be able to implement Bilhikmah method. However, the training involved various methods such as presentation performance, question and asking session, practice, as well as small group and individual mentorship. The result shows that all participated target (100\%) succeed to comprehend the three volumes of Bilhikmah book, while practical tajweed book is mastered by $75 \%$ participants. Furthermore, the training participants are then applied Bilbikmah method on Quran learning process in their own schools.
\end{abstract}

Keywords: Quran reading; Bilhikmah Quran reading method, Islamic primary teacher

\begin{abstract}
Abstrak. Setiap Muslim dituntut untuk bisa membaca Al-Quran. Karena itu salah satu tujuan Pendidikan Agama Islam (PAI) di Sekolah Dasar agar para bisa membaca Al-Quran. Realitasnya hanya sekitar 30\% siswa yang berhasil meraih tujuan pendidikan ini. Salah satu penyebabnya, keliru menerapkan metode pembelajaran. Bilhikmah merupakan metode cepat membaca Al-Quran yang terbukti efektif. Kegiatan pelatiban ini bertujuan membekalkan metode Billikmah kepada para guru PAI SD. Targetnya 75\% dari 40 GURU mampu mengimplementasikan metode Bilhikmah. Pelatihan menggunakan beragam metode, yakni: presentasi, tanya-jawab, demonstrasi, praktek, bimbingan kelompok kecil, dan bimbingan individual. Hasil pelatihan hampir selurub peserta (100\%) berbasil menguasai buku Bilhikmah 1, 2, dan 3, sedangkan buku tajwid praktis dikuasai oleh 75\% peserta. Mereka pun kemudian mengimplementasikan metode Bilhikmah dalam pengajaran membaca Al-Quran di sekolah masing-masing.
\end{abstract}

Kata Kunci: Baca Al-Quran, metode cepat baca Al-Quran Bil hikmah, guru PAI SD 


\section{INTRODUCTION}

The Quran is the most read sacred book, thus reading Quran has become a tradition for Muslim. In the past, specifically in religious places, being able to finish reading Quran (khatam) is considered as a Muslim pride. Many Muslim children are supported to immediately being able to read Quran in a right way, grow a habit to read Quran on a daily basis, and celebrated as a reward. Children whose completed Quran will be paraded around the village on a festive event. In some places, being able to recite Quran completely is considered as the prerequisite on performing a marriage (Rahmat, \& Supriadi, 2011).

Unfortunately, around 1980 - 1990 people were likely reading Quran in lesser intensity. Quran used to be recited after sunset prayer (maghrib), but was decreasingly recited at that time. The number of Quran teachers were decreasing along with the increasing number of televisions for all society strata. The existence of television has been attracting more attention rather than interacting with Quran.

Actually, people's motivation in reading Quran is not degrading but children at that time were starting to prefer an instant process. Whereas Quran learning method was still more traditional at that time (such as Baghdadiyab) which required learners to spell each letter and resulted a long time to fully able to read Quran proficiently. Previously, children were not weary since they tend to learn Quran by playing (having fun) but since in that decade, television was then more preferably favored rather than playing in the mosque. Consequently, the amount of recitation participants is drastically decreased and the number of children with low Quran literacy was increasing. As for instance, total number of students in IKIP Bandung (UPI) which able to read Quran in the range of 1987 - 1992 were approximately around 10\% - $15 \%$. When compared with the resulted data within the range of 2001 - 2010, students with the ability to read Quran were increased by $40 \%-50 \%$. Though recently the number is declining again since between 2001 - 2010, students in UPI are 50\% able to read Quran but in during past three years (2016 - 2018), the average students capable in reading Quran are only 30\% (Supriadi, 2018).

Islamic education in UPI required its students to read and write Quran adequately in order to pass the Islamic Education Test. Nevertheless, since there is no a specific institution which focuses on eradicating the Quran illiteracy number, the lecturers are then applied their own policies. Only few numbers of lecturers conducted ability test in order to facilitate students to read Quran fluently. Mostly, the lecturers are only having the willingness to improve the literacy number in reading Quran but never really executed the plans. The biggest effort done was just by recommending students to join additional curricular lesson in BAQI (Al - Furqon mosque) or in other mosques around students' dwelling and just learning from the students' friends who already capable in reading Quran proficiently. The other lecturers are often not bother to contribute themselves in the pursue of improving students' Quran literacy due to various reasons. Nonetheless, all of lecturers are agreed that students are in the need to recite Quran appropriately.

The inability to read and write Quran has becoming a prominent problem in universities and schools. In two departments within a university was found out that $48 \%$ of students were not able to recite Quran. Similar with UNHAS, around 47\% students on 1998 could not recite Quran properly. Additionally, around 60\% students among all school levels in Bandung were Quran illiterate (Supriadi, 2012).

Bilhikmah method has already been used for many years in Bandung Islamic University (Universitas Islam Bandung / UNISBA). UNISBA has an exclusive program namely students boarding (pesantren mahasiswa). In this program, students are 
taught to appropriately read and write Quran. The result shows that 100\% students in UNISBA are able to be Quran literate. According to Action Research and the latest experience $(1995$ - 1999) executed by Islamic education lecturers in the concerned university, only by conducting a specific Quran lecture for 90 minutes on 12 meetings has significantly affected students to be equipped with appropriate knowledge to master Quran with the note of ratio of one lecturer per 30 students. Additionally, the students who already have more capability would have less learning intensity (Yahya, 2010).

However, UPI is not procured with boarding program yet but at the time being Department of Social Studies UPI has collaborated with Tutorial Program of Islamic education Al-Furqon Mosque and surrounded mosques to establish Tutorial Cepat Baca Quran (an acceleration program to read Quran). The main focus of the department is to eradicate Quran illiteracy. In the continuity, the department has partnership with Yayasan Baitul Hikmah Indonesia (YBHI) which resulted by hundreds of students per semester are becoming more able to recite Quran appropriately. Throughout the training process, trainees are specifically required to grasp Bilhikmah books and the methods to implement the content. Besides, the trainees are also taught about Quran reading Placement Test intended for all students of UPI participating on Islamic education classes on every semester. The obtained data from the placement test is then analyzed further in this research.

The main problem of this research is "how is the effectiveness of Bilhikmah method on teaching Quran for students?"

Bilhikmah book consisted of three volumes (pocket-sized book) with 22 pages for the first volume, 22 pages for second volume, and 34 pages for its third volume. Those volumes are far lighter compared to other manual books on various methods in reciting Quran quickly. Bilhikmah method is efficiently applied in schools, including primary school. The training result is intended as the additional resources towards the relevant previous researches.

The training program is one of the strategies applied by several companies or organizations to improve the competencies of its staffs. Through this systematic program, the staffs are encouraged to increase their knowledge, skills, attitude, and behavior to be actively participated in achieving targeted objectives of the company or organization itself. The program is designed for the staffs to obtain proper competency which in line with their job through acquisition process and skills development along with the additional knowledge and attitudes to be more productive (Cole, 2004). The training program is also intended to upgrade the quality of staffs' well-being (Pallavi \& Kulkarni, 2013) as well as to improve their quality of work performance (Armstrong, 2009).

One study revealed that training is effectively proven to prompt the release of web-based learning media by making used of CMS open source for teachers in SMKSBI (international scale school) in Yogyakarta (Hertanto, Hariyanto Yuniarti, (2008). The training also affecting technical competition positively of governmental institution staffs in West Java (Mulyono \& Meilani, 2016). The other research also stated that the trainees in India are able to completely master the training resources (Rekha \& Ganesh, 2019). Relevant research also showed that there is high number of students' interest in Italy related to entrepreneurship training conducted during the worrying economic issue (Ferri, Ginesti, Spano, and Zampella, 2019). Besides, pre and in service outside from vocational education is Australia also effective in improving the participants' competencies (Smith, Callan, Tuck, and Smith, 2019).

Operationally, this research is projected to answer the following questions: (1) How is the skill level of Islamic primary 
teachers on reciting Quran? (2) To what extent does Bilhikmah method effectively improve the training participants' mastery on Bilhikmah method book and practical tajweed?

\section{METHOD}

Training participants involved in this study is 40 Islamic primary teachers. The training conducted using various methods such as lecturing, question and answer session, performance test, as well as small group and individual mentorship. The training methods are derived as followed:

1. Lecturing, question and answer session, and discussion related to Quran recitation method and approach. In this stage, trainees discussed the advantages of Bilhikmah method based on reliable research results and logical analysis.

2. Introduction and performance test to teach Quran recitation based on Bilhikmah method. The stages started with comprehending volume one of Bilhikmah book which then continued to the second and third volume.

3. Introduction and performance test to apply practical tajweed based on Bilhikmah method. The stages include Quran recitation and teaching process to deliver the contents of each book volume. Then continued with the implementation of the most basic theory and practical knowledge of tajweed.

4. Lastly, the mentorship is conducted to practically apply the method of Bilhikmah.

\section{RESULT AND DISCUSSION}

The main focus of Bilhikmah method training is to enable the trainees to conceive all the three books completely followed by the ability to teach the obtained skill to the others. The effort to enable Islamic education teachers to fully grasp the books are including several necessary stages as followed.

\section{Bilhikmah Book Mastery Training}

Book 1 mastery training involves certain steps as followed:

a. The trainer introduces the pronunciation of bijaiyah letters by associating with the common term on Arabic. The trainees (tutor candidates) are allowed to search other examples by considering the similarity regarding to the fixed principle.

b. Tutor candidates are not allowed to spell bijaiyah letters with harakat (short vowel mark) but are emphasized to read them directly without considering the short and elongation principles.

c. Hijaiyah letters must be memorized. The trainer gave the right examples on how to read the letters followed by the trainees. The trainees need to memorize minimum 2 letters set and maximum 4 letters set.

d. In order to acquaint the characteristic of letters shape, trainees are not only required to associate it soundly but also visually.

e. If the tutorial participants (tutee) got a mistake by reading the letters, the tutor candidates are in the need to directly fix the wrongs by giving the right examples.

f. Tutor candidates are in the need to check tutee's ability to master the appropriate pronunciation of bijaiyah letters randomly as a whole. 
g. Tutor candidates are intended to introduce reading combination by paying attention to the code of vowel mark.

h. If the tutee already able to understand the key point of certain readings, they can continue the reading without being assisted. But just in case there are some mispronunciation, the tutors are in charge to fix it directly.

i. The trainer also reminded that in order to be able to master Quran recitation quickly, the participants are in the need to increase the practices and interaction intensity with the Quran itself.

\section{Bilhikmah Book 2 Mastery Training}

a. The trainer introduces the key of bijaiyah cursive by showing off some examples. The tutor candidates are also taught that there are some exceptions for certain letters which can be turned into cursive.

b. The trainer taught the tutor candidates some codes and principles in which certain letters are in the need to be kept single and some can be transformed into cursive by using props.

c. The trainer instructed the tutor candidates to conduct regular practices and evaluation in turns. If just in case there are some obstacles, they can take a look at the key letter characters.

d. The trainer emphasizes the differences of the way to read noon sukoon within a sentence or at the end of the sentence.

e. The trainer emphasizes the way to teach alif laam qomariyah properly by giving explanation that laam should be read in sukoon clearly. The trainer also gives examples by identifying hijaiyah letters which associated with alif laam qomariyah.

f. The trainer taught the proper way in in reading tashdeed by covering first the sign and compare it with the sentences without tashdeed. Tashdeed is a doubled consonant and a placed sign above the consonant to be doubled. The letter itself is not doubled but only pronounced twice.

g. The trainer explains on how to read alif laam syamsi which makes laam letter does not need to be read. The explanation is completed with the letters group on the set of alif laam syamsi.

h. Lastly, the trainer asked the tutor candidates to fully examine the tutee' ability in combining sukoon, tashdeed and harakat variations. If the tutee are finding it hard, they need to review the key points in slight.

\section{Bilhikmah Book 3 Mastery Training}

a. The trainer explains the way to read short consonants and long vowels, in this case two harakats since it will affect the meaning of the sentences.

b. The trainer emphasizes that the training needs to be conducted carefully by paying attention to the details.

c. The trainer introduces the combination of critical letters with its makhraj (points of articulation of letters) complexity.

d. The trainer introduces the rule of leen which means to read softly or smoothly. This occurs when a word contains a letter of leen and the reader decides to stop on it (whether in the middle or end of an ayah), therefore placing a sukoon on the last letter.

e. The trainer explains the rule of waqf on how sign " $f$ " can be read as " $m$ " on the previous harakat. It is also amplifying the way to read "qaf' and "kaf" nasal when facing with noon sukoon or tanween. 
f. The trainer explains and gives examples to read 6 counts harakat if there is certain sign such as " $\sim$ ".

g. The trainer reminds to conduct evaluation throughout the learning process consistently.

h. Lastly, the trainer explains clearly the points of letter articulation. If the tutee are finding it hard, the tutor should help them to keep practicing the makhraj in every tutorial

After all those three books are mastered, the training is then continued by the practical activity of tajweed.

\section{Training Result}

The training is successfully conducted. However, the result is indicated by answered research questions.

a. The trainees are skilled in reciting Quran. Specifically, 30 training participants $(75 \%)$ are categorized as advanced while 10 training participants $(25 \%)$ are categorized as proficient.

b. The training participants completely participate in all meetings, beginning from the classical class until mentorship program for each small groups and individuals. Those could not attend the classical class were then grouped and taught the left materials.

c. The trainees mastered Bilhikmah books from the first volume to the third volume as well as the book related to practical tajweed rules. The evaluation result regarding to their mastery are given in the table below.
Table 1. Trainees' mastery on Bilhikmah method book

\begin{tabular}{|c|l|c|c|c|}
\hline No. & Bilhikmah Book & Comprehend & Lack Comprehend & Total \\
\hline 1 & Book 1 & 40 & 0 & 40 \\
\hline 2 & Book 2 & 40 & 0 & 40 \\
\hline 3 & Book 3 & 40 & 0 & 40 \\
\hline 4 & Tajweed rules & 30 & 10 & 40 \\
\hline
\end{tabular}

Bilhikmah method books are all fully comprehended by the trainees $(100 \%)$ while the practical tajweed book is only conceived by 30 trainees $(75 \%)$.

The result of this study is relevant with the previous result. It is also found out that the trainees are developing stronger motivation to master Bilhikmah method rather than the obtained result of webbased learning media development training conducted for the teachers from SMK-SBI Yogyakarta. The previous result of webbased learning was implemented by using technology such as CMS (content management system) with open source base. However, the participated trainees are ought to be able to operate computer well [8]. Furthermore, the program which initiated by the current social condition is considered as a firm encouragement for the continuity of one training. Related with the previous result of conducted training for the 941 Italian students, the theme chosen was entrepreneurship which prompted by the current global economy condition. This study adopted the Ajzen planned behavioral theory and used the structural model to identify students' factors in initiating the entrepreneurship program. From the study, it was found out that positive attitudes, subjective norms and behavioral control affect their willingness in starting up an entrepreneurship. Additionally, this result indicated that the skills gained throughout the university scale experience has a significant role in promoting students to consider their own choice on entrepreneurship. Furthermore, the research result acted as a comprehensive 
study which intended for the additional academic resources and entrepreneurship policies [9]. In this case, the training of Bilhikmah method also prompted by the fact that majority of students which have not been able to recite Quran based on the rules and principles. Thus, the teachers are encouraged to learn the method to be redelivered and taught to the students in primary schools.

The success conduction of Bilhikmah method training is also influenced by its novelty and simplicity when compared with the other Quran recitation method. Due to its advantages, the trainees were showing positive impression through learning enthusiasm. This result is in line with the study from Mulyono \& Meilani (2016) that an interesting and innovative training which according to the needs of the participants would optimize the technical competency to improve the work performance based on its function and role. The data analysis also shows that training program conducted for the governmental employees in West Java has a positive impact for their technical competency specifically in developing thinking ability, influencing skill, organizing, and achievements as well [10].

Another factor which affected the result of this study is the delivered sources sequentially. The training participants were required to master the first volume of Bilhikmah method before continuing to the second and the third volume as well as the practical tajweed rules. If during the implementation the trainees faced challenges in teaching Quran to the students, the trainer would directly offer the practical solution. The method by delivering learning sources in sequence had its positive impact as in line with the previous result of conducted web-based learning in Yogyakarta. In the related previous study, the trainees were firstly given the introduction related to internet of things, website, server installation process and CMS software as well. Afterwards, the core material related to web-based learning media development by using CMS open source is delivered. The session then closed by giving the trainees individual task to create their own web-based learning media based on their field of study. In the process of completing individual task, the training participants are given accompaniment in the form of consultation session. Moreover, the individual task is also intended to consider the participants' competency achievements. From overall 11 teachers, all of them could attend the whole training meetings and submitting the task given [8].

Furthermore, the intrinsic willingness from the training participants also act as an important role for the obtained result. The participants involved in Bilhikmah method training were making every effort to grasp the knowledge for the sake of their professionalism as Islamic education teachers. The similar result is conveyed by Rekha \& Ganesh (2019) in India. The conducted research is intended to find out mentors' orientation towards certain trainings and discovered that they did not only attend the training as a knowledge provider for the others, but they also had the willingness to fully master the given sources [11].

Besides, the trainees' familiarity regarding to the method is also considered as a factor to the positive result of this study. Moreover, when the trainees are trained to teach Quran using Bilhikmah method as an effort to eradicate students' Quran illiteracy. The result is in line with the previous result by Smith et, al. (2019) which analyzed the result from research project related to the current trending of employer training in Australia. The educational system and Technical and Vocational Education (VET) training tend to be more investigated rather than the daily trainings took place in the workspace. By considering the entrepreneur survey result in 2015, this study explained and analyzed about Employer Based Training (EBT) in various industrial fields. The survey covered 
various questions such as the reason entrepreneur conducted a training and how it linked to their perceptions related to the operational environment, as well as the structure to organize the training. The detailed data is processed into three types of specific trainings: in-house training, training from external training provider, and national scale training - VET based training. In the end, there is resulted report by the manager related to the obstacles of conducting the trainings. Furthermore, the study analyzed the literature of relevant finding and identified the trainings transformation from time to time in Australia [12]. From that previous result, it can be summarized that pre and in-service training given from the institution aside from formal vocational education is effectively improved the participants' skills.

Overall, Bilhikmah method training is successfully conducted due to the integrated stages of plan, implementation and evaluation. The training also involved Quran tutors from Al - Furqon mosque and students from Islamic Education study program who already understood the strengths and weaknesses on the conduction process of Quran illiteracy eradication program. Presently, the program is kept being conducted to generate the excellent Quran tutors. This finding is in line with research and development result regarding to the general training effectiveness by examining the stages of plan, implementation, and evaluation on training management model development and character building to develop outstanding teacher candidates in disseminating the nation character values. This relevant research used the locus of character development program from Civics Education study program FIS Unnes which included fresh graduated students and young teachers in Semarang, Central Java. The conducted training management factual model and character-building development have its weaknesses reviewed from various aspects such as the plan, implementation and evaluation stages. The reconstruction of conceptual model based on ethical and emic factors are based on the weakness analysis of factual model. Conceptual model is then complemented by accommodating the result of focus group discussion from stake holder and empowering the potential and available sources in the character development division of Civics Education study program Unnes. This model combines various training aspects such as the perfected factual model, consideration of ethics and emic factors, stake holders' aspirations and needs which would worth testing in various and extensive fields (Rachman, Masrukhi; Munandar, and Suhardiyanto, 2017).

\section{CONCLUSION}

Based on the conducted study, it can be concluded that the training of Bilhikmah method is successfully conducted. All of the training participants mastered all volumes of Bilhikmah book and largely are able to master the practical tajweed rules. Furthermore, the conclusions in order to meet the research questions are followed.

1. The training is relatively well conducted since the participants (primary Islamic teachers) are already been able to recite Quran well.

2. All of the training participants had good understanding on Bilhikmah books. They mastered all volumes of Bilhikmah method book and most of them also grasped the practical tajweed principles.

3. The trainees had intention to conduct Quran illiteracy eradication program in their own schools by using Bilhikmah method.

\section{REFERENCES}

Armstrong, M. (2009). Armstrong's handbook of human resource management practice. London: Kogan Page (11 ed.). 
Cole, G.A. (2004). Personnel and buman resource management. Great Britain: Ashford Press.

Ferri, L.; Ginesti, G.; Spano, R.; and Zampella, A. (2019). Exploring factors motivating entrepreneurial intentions: the case of Italian university students. International Journal of Training and Development (Online ISSN:1468-2419), Vol. 22 Issue 3 (First published: 12 August 2019), pp. 202-220, https://doi.org/10.1111/ijtd.12158.

Hertanto, D.B.; Hariyanto, D.; and Yuniarti, N. (2008). Pelatihan dan Pendampingan Pembuatan Media Pembelajaran Berbasis Web dengan Menggunakan CMS (Content Management System) Open Source Bagi Guru-Guru SMK-SBI SePropinsi DIY. Artikel Jurnal. Lembaga Pengabdian Kepada Masyarakat Universitas Negeri Yogyakarta.

Mulyono, T. \& Meilani, R.I. (2016). Dampak Program Pelatihan Terhadap Tingkat Kompetensi Teknis Pegawai. MANPER - Jurnal Pendidikan Manajemen Perkantoran, Vol. 1 No. 1 (Agustus 2016), pp. 167-175.

Pallavi, M.S. \& Kulkarni, P. (2013). A Literature Review On Training. Journal of Arts, Science \& Commerce, Vol. IV No. 2 (April 2013)), pp. 136143.

Rachman, M.; Masrukhi; Munandar, A.; and Suhardiyanto, A. (2017).

Pengembangan Model Manajemen Pelatihan Dan Pengembangan Pendidikan Karakter Berlokus Padepokan Karakter. Jurnal Refleksi Edukatika, Vol. 8 No. 1 (December 2017), pp. 16-26.

Rahmat, M. \& Supriadi, U. (2011). "Studi Efektivitas Kutab Bilhikmah dalam Meningkatkan Kemampuan Membaca Al-Quran pada Mahasiswa UPI Peserta Tutorial PAI." Artikel Hasil Penelitian. Departemen Pendidikan Umum FPIPS UPI.
Rekha, K.N. \& Ganesh, M.P. (2019). Factors influencing mentors' learning from mentoring relationships: insights from a serial mediation study in India. International Journal of Training and Development (Online ISSN:14682419), Vol. 22 Issue 3 (First published: 29 July 2019), pp. 221-239, https://doi.org/10.1111/ijtd.12159.

Smith, E.: Callan, V.; Tuck, J.; and Smith, A. (2019). Employer training in Australia: current practices and concerns. International Journal of Training and Development (Online ISSN:1468-2419), Vol. 22 Issue 2 (First published: 9 June 2019), pp. 169-183, https://doi.org/10.1111/ijtd.12152.

Supriadi, Udin (2012). "Tingkat Kemampuan Membaca Al-Quran Mahasiswa UPI Bandung". Laporan Penelitian. Program Studi Ilmu Pendidikan Agama Islam UPI. Supriadi, Udin (2018). "Tingkat

Kemampuan Membaca Al-Quran Mahasiswa UPI Bandung". Laporan Penelitian. Program Tutorial PAI Departemen Pendidikan Umum UPI. Yahya, M.W. (2010)."Efektivitas Metode Bilhikmah dalam Memberantas Buta Huruf Al-Quran Anak TK dan Mahasiswa UNISBA". Laporan Penelitian. Fakultas Ushuluddin UNISBA. 